\title{
The Total Carbon Column Observing Network site description for Lauder, New Zealand
}

\author{
David F. Pollard ${ }^{1}$, Vanessa Sherlock ${ }^{1}$, John Robinson ${ }^{1}$, Nicholas M. Deutscher ${ }^{2}$, Brian Connor ${ }^{3}$, and \\ Hisako Shiona ${ }^{1}$ \\ ${ }^{1}$ National Institute of Water and Atmospheric Research Ltd (NIWA), Lauder, New Zealand \\ ${ }^{2}$ School of Chemistry, University of Wollongong, Northfields Ave, Wollongong, NSW, 2522, Australia \\ ${ }^{3}$ BC Consulting Limited, Martinborough, New Zealand
}

Correspondence to: David F. Pollard (dave.pollard@niwa.co.nz)

Received: 30 June 2017 - Discussion started: 12 July 2017

Revised: 25 October 2017 - Accepted: 2 November 2017 - Published: 7 December 2017

\begin{abstract}
In this paper we describe the retrievals of atmospheric trace gases from near-infrared, high-resolution solar absorption spectroscopy measurements at the Lauder atmospheric research station in New Zealand and submitted to the Total Carbon Column Observing Network (TCCON) archive.

The Lauder site $\left(45.034^{\circ} \mathrm{S}, 169.68^{\circ} \mathrm{E}, 370 \mathrm{~m}\right.$ a.s.l. $)$ is located within a sparsely populated region of the South Island of New Zealand and is sheltered from the prevailing wind direction by the Southern Alps, which gives the site a high number of clear-sky days and an air mass that is largely unmodified by regional anthropogenic sources. The Lauder TCCON archive consists of data from two instruments: a Bruker IFS 120HR from June 2004 to February 2010 and a Bruker IFS 125HR from February 2010 to present. The bias between the two instruments is assessed to be $0.068 \%$ for $\mathrm{CO}_{2}$. Since measurements using the IFS $125 \mathrm{HR}$ began, the SD about the hourly mean has been better than $0.1 \%$ for $96.81 \%$ of $\mathrm{CO}_{2}$ column retrievals.

The retrievals have been calibrated against in situ airborne measurements to correct for biases and provide traceability to the World Meteorological Organization (WMO) scales with an accuracy of $0.1 \%$ for $\mathrm{CO}_{2}$.

The Lauder TCCON time series of retrieved dry-air mole fractions of $\mathrm{CO}_{2}, \mathrm{CH}_{4}, \mathrm{~N}_{2} \mathrm{O}, \mathrm{HF}, \mathrm{H}_{2} \mathrm{O}, \mathrm{HDO}$ and $\mathrm{CO}$ are available from the TCCON data archive.

The DOIs are

https://doi.org/10.14291/tccon.ggg2014.lauder01.R0/1149293 for the IFS 120HR data

https://doi.org/10.14291/tccon.ggg2014.lauder02.R0/1149298 for the IFS 125HR data.
\end{abstract}

\section{Introduction}

Atmospheric trace gases that absorb infrared radiation have an important influence on the Earth's climate due to the greenhouse effect. Accumulation of some of these species, most notably carbon dioxide $\left(\mathrm{CO}_{2}\right)$ and methane $\left(\mathrm{CH}_{4}\right)$, are causing changes to the global radiation budget, which in turn is modifying the climate system. In order to understand the direct and indirect influences this process is having on the climate, it is important to understand the global distribution, sources and sinks of these gases.

One method for measuring the total column abundance of these gases is high-resolution solar absorption spectroscopy using Fourier transform spectrometers (FTSs) in the nearinfrared spectral region. The Total Carbon Column Observing Network (TCCON, Wunch et al., 2011a) consists of a geographically dispersed network of such instruments designed to provide consistent and precise retrievals of a number of the atmospheric species. For $\mathrm{CO}_{2}$ column measurements, Rayner and O'Brien (2001) demonstrated that a precision of better than $0.25 \%$ is necessary to improve understanding of the carbon cycle while Olsen and Randerson (2004) showed that a precision of better than $0.1 \%$ would allow the strength of the Northern Hemisphere carbon sink to be assessed. The TCCON has adopted these values as measurement precision 
Table 1. Instrument information.

\begin{tabular}{lllllll}
\hline Date & Instrument & Detectors & Spectral range & $\begin{array}{l}\text { LSE correc- } \\
\text { tion method }\end{array}$ & $\begin{array}{l}\text { Data processing } \\
\text { version }\end{array}$ & $\begin{array}{l}\text { TCCON } \\
\text { archive name }\end{array}$ \\
\hline $\begin{array}{l}\text { 20 Jun 2004- } \\
\text { 28 Feb 2011 }\end{array}$ & $120 \mathrm{HR}$ & $\begin{array}{l}\text { Extended } \\
\text { InGaAs }\end{array}$ & $3900-9000 \mathrm{~cm}^{-1}$ & None & GGG2014R01 & lauder01 \\
\hline $\begin{array}{l}\text { 02 Feb 2010- } \\
\text { present }\end{array}$ & $125 \mathrm{HR}$ & $\begin{array}{l}\text { Extended } \\
\text { InGaAs }+\mathrm{Si}\end{array}$ & $3900-15000 \mathrm{~cm}^{-1}$ & Si-based & GGG2014R01 & lauder02 \\
\hline
\end{tabular}

targets for the network with an expected site-to-site bias of less than $0.2 \%$ (Wunch et al., 2015).

In this paper we describe the TCCON site at Lauder, New Zealand (45.034 ${ }^{\circ} \mathrm{S}, 169.68^{\circ}$ E, 370 ma.s.l.), and the time series of column-averaged dry-air mole fractions (DMFs, denoted by $\left.X_{\text {gas }}\right)$ of $\mathrm{CO}_{2}, \mathrm{CH}_{4}$, nitrous oxide $\left(\mathrm{N}_{2} \mathrm{O}\right)$, hydrogen fluoride (HF), water vapour $\left(\mathrm{H}_{2} \mathrm{O}\right.$ and $\left.\mathrm{HDO}\right)$ and carbon monoxide (CO), which have been retrieved using the 2014 version of the GGG processing software (Wunch et al., 2015) and are archived on the TCCON data archive (Sherlock et al., 2014a, b). This time series spans from 2004 to the present and represents the longest TCCON dataset in the Southern Hemisphere.

TCCON data from Lauder have been used extensively to support satellite missions, such as the Greenhouse Gases Observing Satellite (GOSAT, Yokota et al., 2009; Wunch et al., 2011b; Crisp et al., 2012) and the Orbiting Carbon Observatory 2 (OCO-2, Crisp et al., 2008), by providing data for retrieval validation and algorithm development (e.g. Schepers et al., 2016; Dupuy et al., 2016; Connor et al., 2016; Wunch et al., 2016), as well as for carbon cycle studies and model validation (e.g. Chevallier et al., 2011; Deutscher et al., 2014).

\section{Site details}

The Lauder atmospheric research station, operated by New Zealand's National Institute of Water and Atmospheric Research (NIWA), is located in a sparsely populated rural area on the South Island of New Zealand. The station is $2 \mathrm{~km}$ north of the settlement of Lauder (population of approximately 50) in a broad valley with mountain ranges on three sides. Prevailing westerly winds have to cross the Southern Alps before reaching the site, and this orographic drying leads to annual rainfall of around $400 \mathrm{~mm}$ evenly distributed throughout the year, resulting in a semi-arid climate with a high number of clear-sky days.

Land around the site is predominantly used for irrigated livestock grazing or seasonal cropping or it is dry scrub. Farming practices in the area have shifted in recent years from low-intensity sheep and cattle grazing to more intensive dairy farming with a corresponding change from flood to spray irrigation. Some upland farming takes place in the region, which sometimes requires austral springtime tussock burn off. Plumes from this biomass burning may affect in situ measurements at the site on a small number of days each year.

In the region, most domestic heating is by wood burning. The nearest major population centre is the township of Alexandra, with a population of approximately 5000, located $40 \mathrm{~km}$ southwest of the site. Although air quality in this and other settlements in the region suffers from the inefficient burning of wood, in most cases these plumes are capped by an inversion layer and drain away from the research station, rarely affecting measurements. There are no other major anthropogenic sources of greenhouse gases or pollutants in the region.

Southern New Zealand is exposed to strong westerly flows that have had little or no interaction with significant land masses. Consequently, the atmospheric composition observed at the site can be considered representative of the atmospheric background state (Steinkamp et al., 2017).

As well as being part of TCCON, the Lauder station is a member of the Network for the Detection of Atmospheric Composition Change (NDACC), the Baseline Surface Radiation Network (BSRN), Global Atmosphere Watch (GAW) and the GCOS (Global Climate Observing System) Reference Upper-Air Network (GRUAN).

Other greenhouse gas measurements are also made at the site; these are summarised in Sect. 3.4.

\section{Instrumentation}

Two FTS instruments have been used to make TCCON measurements at Lauder (Table 1); the chronology of these instruments and major changes to them are listed in Table 2.

Both instruments are accommodated in a dedicated, air conditioned and temperature-stabilised laboratory. Both have dedicated solar trackers, protected by autonomous covers, which close automatically in the event of rain or high winds.

\subsection{Bruker IFS 120HR}

From June 2004, following the installation of an indium gallium arsenide (InGaAs) detector, an existing Bruker 120HR FTS (referred to as lauder01 in the TCCON archive) was used in a time-sharing mode to make routine measurements of solar absorption in the mid-infrared (MIR, for the 
Table 2. Major events.

\begin{tabular}{|c|c|c|c|}
\hline Date & Instrument & Details & Impact \\
\hline 30 Mar 2004 & $120 \mathrm{HR}$ & First NIR measurements & \\
\hline 20 Jun 2004 & $120 \mathrm{HR}$ & Start of TCCON archived data & \\
\hline 30 May 2006 & $120 \mathrm{HR}$ & $\begin{array}{l}\text { Change to using single scans instead of co- } \\
\text { added interferograms and from } 20 \text { to } 40 \mathrm{kHz} \\
\text { scan rate }\end{array}$ & \\
\hline 1 Apr 2009 & $120 \mathrm{HR}$ & Laser change & \\
\hline 1 Aug 2009 & $125 \mathrm{HR}$ & Instrument installed & \\
\hline 2 Feb 2010 & $125 \mathrm{HR}$ & Start of TCCON archived data & \\
\hline 28 Feb 2010 & $120 \mathrm{HR}$ & End of TCCON archived data & \\
\hline 17-25 Mar 2010 & $125 \mathrm{HR}$ & Shear alignment & \\
\hline 7-14 Apr 2010 & $125 \mathrm{HR}$ & IR beam steer alignment & \\
\hline 1-7 Jul 2010 & $125 \mathrm{HR}$ & $\begin{array}{l}\text { Alignment using Hase and Blumenstock } \\
\text { method }\end{array}$ & \\
\hline 5 Oct 2010-20 Jan 2011 & $125 \mathrm{HR}$ & Timing errors & $X_{\text {air }}$ uncertainty increased \\
\hline 20 Jan 2011 & $125 \mathrm{HR}$ & Laser sampling board replaced & \\
\hline 18 Mar 2011 & $125 \mathrm{HR}$ & New $\mathrm{CaF}_{2}$ beam splitter installed & \\
\hline 4-11 May 2011 & $125 \mathrm{HR}$ & Alignment optimised & \\
\hline 20 Apr 2012 & $125 \mathrm{HR}$ & Laser replaced & Ghosts minimised 24 Apr 2012 \\
\hline 12 Sep-24 Oct 2012 & $125 \mathrm{HR}$ & Timing errors & $X_{\text {air }}$ uncertainty increased \\
\hline 21 and 24 Oct 2013 & $125 \mathrm{HR}$ & $\begin{array}{l}\text { Measurements affected by smoke from } \\
\text { Australian bushfires. }\end{array}$ & Data excluded from archive \\
\hline 12 Sep-24 Oct 2012 & $125 \mathrm{HR}$ & Timing errors & $X_{\text {air }}$ uncertainty increased \\
\hline 09 Mar-30 Jun 2014 & $125 \mathrm{HR}$ & Timing errors & $X_{\text {air }}$ uncertainty increased \\
\hline 28 Sep-1 Oct 2014 & $125 \mathrm{HR}$ & Timing errors & $X_{\text {air }}$ uncertainty increased \\
\hline 5 Jan 2015 & $125 \mathrm{HR}$ & Laser replaced & Ghosts minimised \\
\hline 28 Jan 2015 & $125 \mathrm{HR}$ & Laser replaced & Ghosts minimised \\
\hline 20 Oct-16 Nov 2015 & $125 \mathrm{HR}$ & $\begin{array}{l}\text { Control electronics upgrade and various } \\
\text { firmware updates }\end{array}$ & Some data lost \\
\hline 30 Mar 2016 & $125 \mathrm{HR}$ & Switch from scan rate of 20 to $10 \mathrm{kHz}$ & \\
\hline
\end{tabular}

NDACC) and near-infrared (NIR, for the TCCON). Acquisition of spectra in the two spectral regions (MIR and NIR) requires a beam splitter exchange, necessitating daily venting and re-evacuation of the instrument (and loss of observation time for the original MIR measurement programme). This was the operational TCCON instrument from 20 June 2004 until 28 February 2010. From 20 June 2004 to 30 May 2006, each retrieval consisted of 10 co-added interferograms measured at a scanner velocity of $20 \mathrm{kHz}$. After this period retrievals were made from individual interferograms measured at $40 \mathrm{kHz}$.

A prototype active tracking system was installed in the IFS 120HR solar tracker telescope in 2006, which adjusted the position of a $45^{\circ}$ mirror immediately before the instrument input port based on feedback from quadrant diodes. The in-house-developed NIWA360 tracker as used by the IFS 125HR instrument was not installed for the IFS 120HR until 2011, after the end of the lauder01 dataset.

After installation of the IFS 125HR instrument (see below) 1 month of measurements using both instruments have been released to the TCCON archive to allow users to assess any biases between instruments. An assessment of bias between instruments is also made in Sect. 7.1.

Measurements in TCCON mode are still made periodically (approximately monthly) with this instrument to provide an independent check of the primary TCCON instrument. These data are not released to the TCCON archive.

\subsection{Bruker IFS 125HR}

In 2009 NIWA purchased a Bruker IFS 125HR spectrometer dedicated to TCCON measurements (lauder02 in the TCCON data archive). This instrument began routine TCCON measurements in February 2010.

Active tracking for this instrument is achieved using the in-house-developed NIWA360 system, which directs a small amount of the incoming solar radiation through a telescope and onto quadrant photo diodes, which steer the tracker to keep the solar image centred on the FTS input aperture to within $10 \%$ of the radial extent of the solar disc, an accuracy of better than $0.025^{\circ}$. The NIWA360 system has been used for the IFS 125HR since installation.

As with most TCCON sites, this instrument was originally supplied with a faulty ECL03 laser sampling board, resulting 
Table 3. Airborne calibration flights at the Lauder TCCON site.

\begin{tabular}{|c|c|c|c|c|c|}
\hline Campaign & Flight & Date & Alt. range & TCCON instrument & Species compared \\
\hline HIPPO 1 & RF 7 & 21 Jan 2009 & $0.7-14.6 \mathrm{~km}$ & $120 \mathrm{HR}$ & $\mathrm{CO}_{2}, \mathrm{CH}_{4}, \mathrm{CO}$ and $\mathrm{N}_{2} \mathrm{O}$ \\
\hline HIPPO 2 & RF 5 & 10 Nov 2009 & $0.8-13.1 \mathrm{~km}$ & $120 \mathrm{HR}$ & $\mathrm{CO}_{2}, \mathrm{CH}_{4}, \mathrm{CO}$ and $\mathrm{N}_{2} \mathrm{O}$ \\
\hline HIPPO 3 & RF 6 & 6 Apr 2010 & $0.6-12.9 \mathrm{~km}$ & $125 \mathrm{HR}$ & $\mathrm{CO}_{2}, \mathrm{CH}_{4}, \mathrm{CO}$ and $\mathrm{N}_{2} \mathrm{O}$ \\
\hline HIPPO 5 & RF 8 & 28 Aug 2011 & $2.7-13.7 \mathrm{~km}$ & $125 \mathrm{HR}$ & $\mathrm{CO}_{2}, \mathrm{CH}_{4}, \mathrm{CO}$ and $\mathrm{N}_{2} \mathrm{O}$ \\
\hline HIPPO 5 & RF 9 & 30 Aug 2011 & $2.8-14.1 \mathrm{~km}$ & $125 \mathrm{HR}$ & $\mathrm{CO}_{2}, \mathrm{CH}_{4}, \mathrm{CO}$ and $\mathrm{N}_{2} \mathrm{O}$ \\
\hline AirCore & 1 & 9 Sep 2015 & $0.7-16.0 \mathrm{~km}$ & $125 \mathrm{HR}$ & $\mathrm{CO}_{2}$ and $\mathrm{CH}_{4}$ \\
\hline AirCore & 2 & 11 Sep 2015 & $1.2-21.0 \mathrm{~km}$ & $125 \mathrm{HR}$ & $\mathrm{CO}_{2}$ and $\mathrm{CH}_{4}$ \\
\hline
\end{tabular}

in spurious "ghost" signals, which interfere with the spectral fitting. The electronics board in the Lauder IFS 125HR was upgraded to an ECL05 board in January 2011 and the ghost-to-parent ratio (GPR) has since been monitored regularly and minimised whenever necessary. A full discussion on the treatment of this issue is given in Sect. 4.1.

Apart from some early testing between February and October 2010 when some measurements were taken at scanner velocities of 10 and $40 \mathrm{kHz}$, the majority of the IFS $125 \mathrm{HR}$ time series have been taken at $20 \mathrm{kHz}$. Following the installation of new control electronics in October 2015, measurements were transitioned to $10 \mathrm{kHz}$ at the end of March 2016 .

\subsection{Auxiliary measurements}

In order to satisfy the requirements of a TCCON station, and to carry out retrievals, a number of auxiliary measurements of meteorological parameters are required. A NIWA climate monitoring station is sited at Lauder, approximately $220 \mathrm{~m}$ from the FTS instruments. This includes measurements of

- pressure: Vaisala PTB100A $\pm 0.3 \mathrm{hPa}$.

- temperature and humidity: Vaisala HMP155D $\pm 0.3{ }^{\circ} \mathrm{C}$, $\pm 3.5 \%$.

- wind speed and direction: Vector A101M anemometer $\left( \pm 0.1<10 \mathrm{~m} \mathrm{~s}^{-1}, \pm 2 \%\right.$ rest of range) and Vector W200P vane $\left( \pm 2^{\circ}\right)$.

\subsection{Other instruments present at the site}

The atmospheric research station at Lauder hosts a wide range of atmospheric remote sensing and in situ instrumentation. With respect to atmospheric greenhouse gas measurements, these include in situ FTS measurements of $\mathrm{CO}_{2}, \mathrm{CO}$, $\mathrm{CH}_{4}$ and $\mathrm{N}_{2} \mathrm{O}$ (Griffith et al., 2012), non-dispersive infrared (NDIR) measurements of $\mathrm{CO}_{2}$ using a LI-COR LI-7000 instrument and flask samples for subsequent measurements of $\mathrm{CO}_{2}, \mathrm{CO}, \mathrm{CH}_{4}, \mathrm{~N}_{2} \mathrm{O}$ and stable isotopologues of $\mathrm{CO}_{2}$, which are collected between 15:00 and 16:00 NZST when the wind speed is above $5 \mathrm{~m} \mathrm{~s}^{-1}$ in order to sample a well mixed boundary layer (Brailsford et al., 2012). The in situ measurements at Lauder are described more fully in Appendix A of
Steinkamp et al. (2017). The site also hosts lidar measurements of ozone and aerosols.

\section{Data processing}

The TCCON uses a common processing and retrieval system known as GGG (currently version GGG2014 described by Wunch et al., 2015) in order to minimise biases across the network. This section will describe the data processing as it applies to the IFS 125HR data. The processing is broadly similar for IFS 120HR except that for the IFS 120HR the Silicon (Si) detector is not used, only forward scan interferograms are recorded and in principle there is no requirement to correct for laser sampling errors because the IFS 120HRs did not contain the defective laser sampling boards.

The IFS 125HR records direct-current-corrected, dual channel (InGaAs and $\mathrm{Si}$ ), forward and reverse scan interferograms throughout the day whenever there are clear skies. After each day of measurements, the interferograms are assessed visually by the operator to check for data quality to remove any periods of total cloud contamination. The raw interferograms are then processed by the I2S (interferogramto-spectrum) software package, which corrects for solar intensity fluctuations (Keppel-Aleks et al., 2007), applies a phase correction (Mertz, 1967) and a laser sampling error (LSE) correction (Sect. 4.1 below), and then computes the spectra using a fast Fourier transform (Bergland, 1969). The causes and mitigation of the LSE are described later in this section.

The resulting spectra are analysed using the GFIT nonlinear, least-squares fitting algorithm, which uses molecular absorption coefficients, a priori estimates of gas mole fraction profiles, profiles of temperature, pressure, and humidity and the calculated solar viewing geometry to calculate theoretical absorption spectra. The atm.101 spectral line list (Toon, 2014a) used is based on the HITRAN2012 database (Rothman et al., 2013) with exceptions as described in Wunch et al. (2011a, 2015). The solar line list used is that of Toon (2014b).

The profiles of temperature, pressure and humidity are interpolated to the site location from the National Centers for 
Environmental Prediction (NCEP) reanalysis data (Kalnay et al., 1996) for local noon.

A priori profiles of all retrieved species other than water vapour are generated using a set of empirical functions that are optimised to fit observations from a number of different in situ, aircraft and balloon, and satellite sources as a function of latitude, longitude and season, as well as taking account of long-term variability. The GGG2014 a priori profiles can be generated using a stand-alone Fortran program (Toon and Wunch, 2014).

GFIT then compares the theoretical and measured spectra in a number of independent micro-windows and minimises the RMS difference between them by iteratively scaling the assumed gas profiles and fitting spectroscopic characteristics such as continuum level, tilt and some degree of curvature, and frequency shifts.

In order to reduce the sensitivity of the measurement to variations in surface pressure and atmospheric water vapour, TCCON reports the column-averaged dry-air mole fractions (DMFs or $X_{\text {gas }}$ ), calculated by dividing the column of gas by the column of dry air inferred from the co-retrieved $\mathrm{O}_{2}$ column multiplied by the assumed dry-air mole fraction of $\mathrm{O}_{2}$ :

$X_{\text {gas }}=\frac{\mathrm{VC}_{\text {gas }}}{\mathrm{VC}_{\mathrm{O}_{2}}} \cdot 0.2095$.

This scaling by the retrieved $\mathrm{O}_{2}$ column also reduces the effect of systematic instrumental biases such as timing or pointing errors.

The DMF of dry air, $X_{\text {air }}$, is a special case given by

$X_{\text {air }}=\frac{\mathrm{VC}_{\text {air }}}{\mathrm{VC}_{\mathrm{O}_{2}}} \cdot 0.2095-X_{\mathrm{H}_{2} \mathrm{O}} \cdot \frac{m_{\mathrm{H}_{2} \mathrm{O}}}{m_{\text {air }}^{\text {dry }}}$,

where $m_{\mathrm{H}_{2} \mathrm{O}}$ and $m_{\text {air }}^{\text {dry }}$ are the mean molecular masses of water $\left(18.02 \mathrm{~g} \mathrm{~mol}^{-1}\right)$ and dry air $\left(28.964 \mathrm{~g} \mathrm{~mol}^{-1}\right), X_{\mathrm{H}_{2} \mathrm{O}}$ is the retrieved $\mathrm{DMF}$ of water vapour and $\mathrm{VC}_{\text {air }}$ is calculated from the surface pressure, $P_{\mathrm{s}}$.

$$
V C_{\text {air }}=\frac{P_{\mathrm{s}}}{\{g\} \cdot \frac{m_{\text {air }}^{\text {dry }}}{N_{\mathrm{a}}}},
$$

where $\{g\}$ is the column-averaged acceleration due to gravity and $N_{\mathrm{a}}$ is Avogadro's constant.

In the case of a perfectly accurate measurement, the value of $X_{\text {air }}$ would be unity. Due to spectroscopic limitations the actual value is approximately 0.98 for all TCCON sites and varies by approximately $1 \%$ with solar zenith angle. Deviations from the characteristic values for $X_{\text {air }}$ are generally indicative of erroneous behaviour in the measurement and retrieval system such as tracking errors or fitting to an incorrect air mass as described in Sect. 5.2. However, these errors will generally cancel out in the calculation of DMFs of individual gases as the error will be present for both the gas and $\mathrm{O}_{2}$.
As detailed elsewhere (Deutscher et al., 2010; Wunch et al., 2011a, 2015), the TCCON $X_{\mathrm{CO}_{2}}$ data exhibit nonphysical symmetric variability with changing air mass. The data presented here have the TCCON standard air mass correction of -0.0068 applied; however, this value is derived from a limited time series of data from three sites only. Calculating the corresponding value from the uncorrected Lauder $X_{\mathrm{CO}_{2}}$ data yields an air mass correction of $-0.0095 \pm$ 0.0021 ; applying this value to the Lauder $X_{\mathrm{CO}_{2}}$ time series generates a seasonal cycle amplitude that is $\pm 0.6 \mu \mathrm{mol} \mathrm{mol}^{-1}$ smaller. Users for whom the seasonal variability is critical can circumvent this issue by only selecting $X_{\mathrm{CO}_{2}}$ values corresponding to a restricted range of solar zenith angles (SZAs) that is consistent throughout the entire year, e.g. only using measurements between 35 and $55^{\circ} \mathrm{SZA}$, at which the air mass correction is smallest.

A network-wide bias correction based on airborne measurements to provide traceability to WMO trace gas scales as described in Wunch et al. (2010) with updated values from Wunch et al. (2015), listed in the second column of Table 4, is also applied. The Lauder-specific calibration campaigns are described in Sect. 6 of this article.

\subsection{Laser sampling error correction}

The IFS 125HR FTS makes use of a helium-neon (HeNe) metrology laser running parallel to the measured solar beam in the interferometer to allow accurate measurement and control of the optical path difference by counting interference fringes. A fault with the original ECL03 laser amplifier board supplied with this instrument meant that the metrology laser was not sampled correctly at the zero crossing point between the peak and trough of the resulting sine wave (Messerschmidt et al., 2010). As a result, some of the spectral information above the Nyquist frequency of $7899 \mathrm{~cm}^{-1}$ was folded below it and vice versa, causing features known as ghosts.

During installation the LSE was minimised for a scanner velocity of $40 \mathrm{kHz}$, resulting in a small LSE at a rate of $20 \mathrm{kHz}$ used for the majority of operational measurements.

Following the discovery of this fault, Bruker supplied all TCCON sites with replacement ECL05 laser amplifier boards, which allowed the zero level (i.e. the level at which the electronics identify the zero crossing point) to be adjusted. The rectified electronics board was installed in the Lauder IFS 125HR in January 2011. Since this time, regular (approx. every 3 months) checks have been conducted to check for the presence of ghosts and to minimise them by adjusting the zero level if necessary. This is achieved by taking measurements of a tungsten lamp, placing a band pass filter $\left(5500-6600 \mathrm{~cm}^{-1}\right)$ between the interferometer and detector, and measuring the signal aliased at $9800 \mathrm{~cm}^{-1}$. If any signal is detected, the zero level is iteratively adjusted in order to minimise it. 


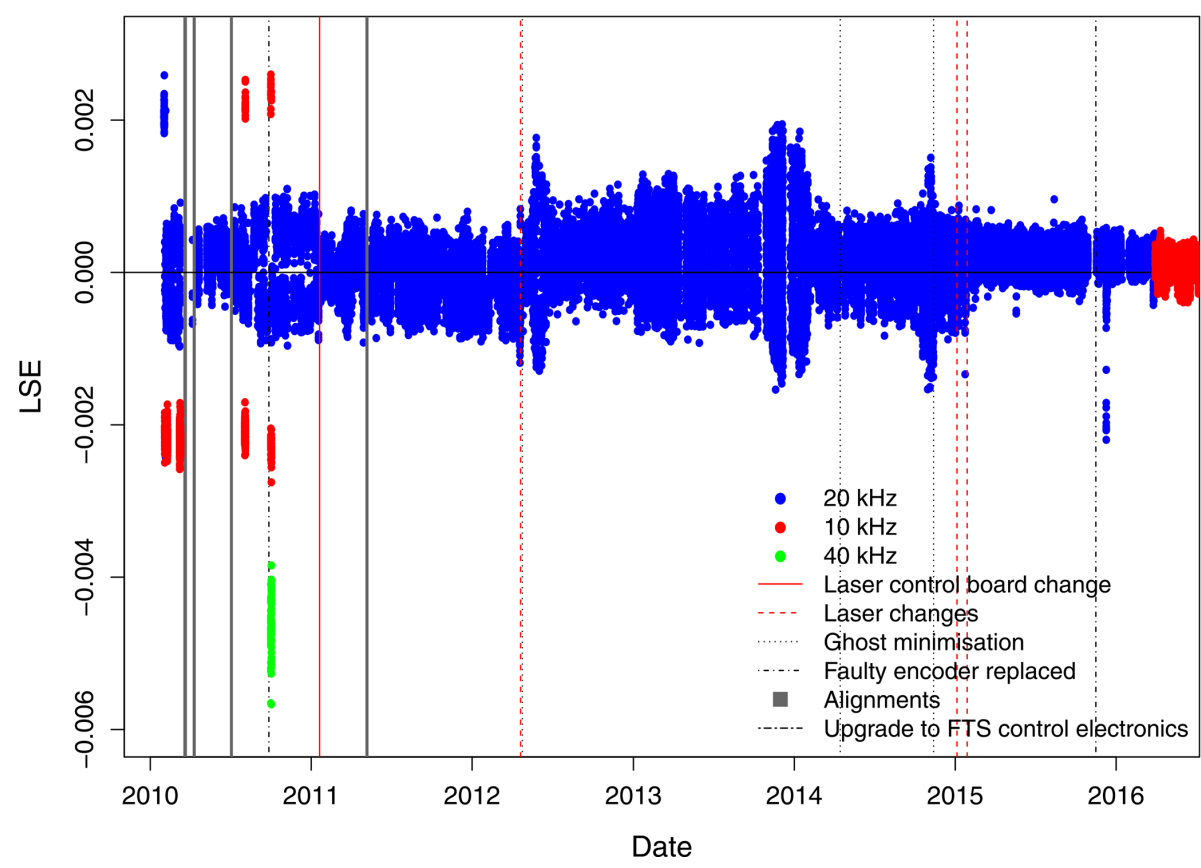

Figure 1. Time series of LSE calculated using the I2S algorithm for the IFS $125 \mathrm{HR}$ spectra. For $20 \mathrm{kHz}$ data only every 10 th data point is plotted for clarity. Vertical lines show significant changes or adjustments to the instrument.

The 2014 release of the GGG processing software I2S algorithm makes use of the spectra recorded using the Si detector, which is wholly contained in the upper half of the alias, to derive the magnitude of the LSE and allow the spectra of both detectors to be resampled, removing the ghost signal. This method is described fully in Wunch et al. (2015).

Figure 1 shows the time series of LSE determined using the I2S algorithm over the period of measurements made using the IFS 125HR. Periods of instrument alignment are denoted by the shaded vertical bands whilst other notable instrument changes are indicated by the various vertical lines. The solid vertical line in early 2011 represents the change of laser amplifier board and subsequent improvement in LSE. Also of note is the change in LSE performance with individual metrology lasers, with the performance of the unit installed between April 2012 and January 2015 being poorer and less stable than other devices as indicated by the relative scatter in the derived LSEs.

\section{Instrument stability}

\subsection{Instrumental line shape}

The performance and alignment of both instruments is monitored through monthly retrievals of the instrumental line shape (ILS) from spectra obtained from a lamp source with a reference hydrogen chloride $(\mathrm{HCl})$ cell, using the LINEFIT 14 software (Hase et al., 2013). The retrieved ILS describes the deviation from a theoretical ideal ILS, which is assumed by the GFIT retrieval code, in terms of the modulation effi- ciency (ME) and phase error, both of which vary as a function of optical path difference (OPD) of the interferometer. In the following discussion, ME will refer to the modulation efficiency at the maximum OPD of $45 \mathrm{~cm}$ used for TCCON measurements.

Figure 2 shows a time series of the retrieved ME and maximum phase error for both instruments. For the IFS 125HR, the mean of the ME is 0.9995 with a SD of 0.0106 indicating the stability of the instrument optical alignment over time. This value is significantly better than $4 \%$ deviation in ME, which Hase et al. (2013) demonstrated was necessary in order to achieve the $X_{\mathrm{CO}_{2}}$ retrieval accuracy required by the TCCON. The results for the IFS $120 \mathrm{HR}$ show more scatter and less stability, with a mean of 1.0124 and SD of 0.0256 . Regular ILS retrievals from lamp spectra have been carried out since August 2010.

\subsection{IFS 125HR timing errors}

Due to the instability of the IFS $125 \mathrm{HR}$ instrument's internal clock, there have been a number of occasions when timing errors have been noted in the retrieved data. These are listed in Table 2. The errors have generally occurred when updates to the operating system or experimental set-up have prevented the instrument control computer from periodically resetting the time in the instrument's firmware. Such errors cause the retrieval scheme to attempt to fit the spectra to an incorrect air mass due to small differences in the calculated and true SZA. At the magnitude at which these errors occurred, the effect on the retrieved $X_{\text {gas }}$ values is negligible 


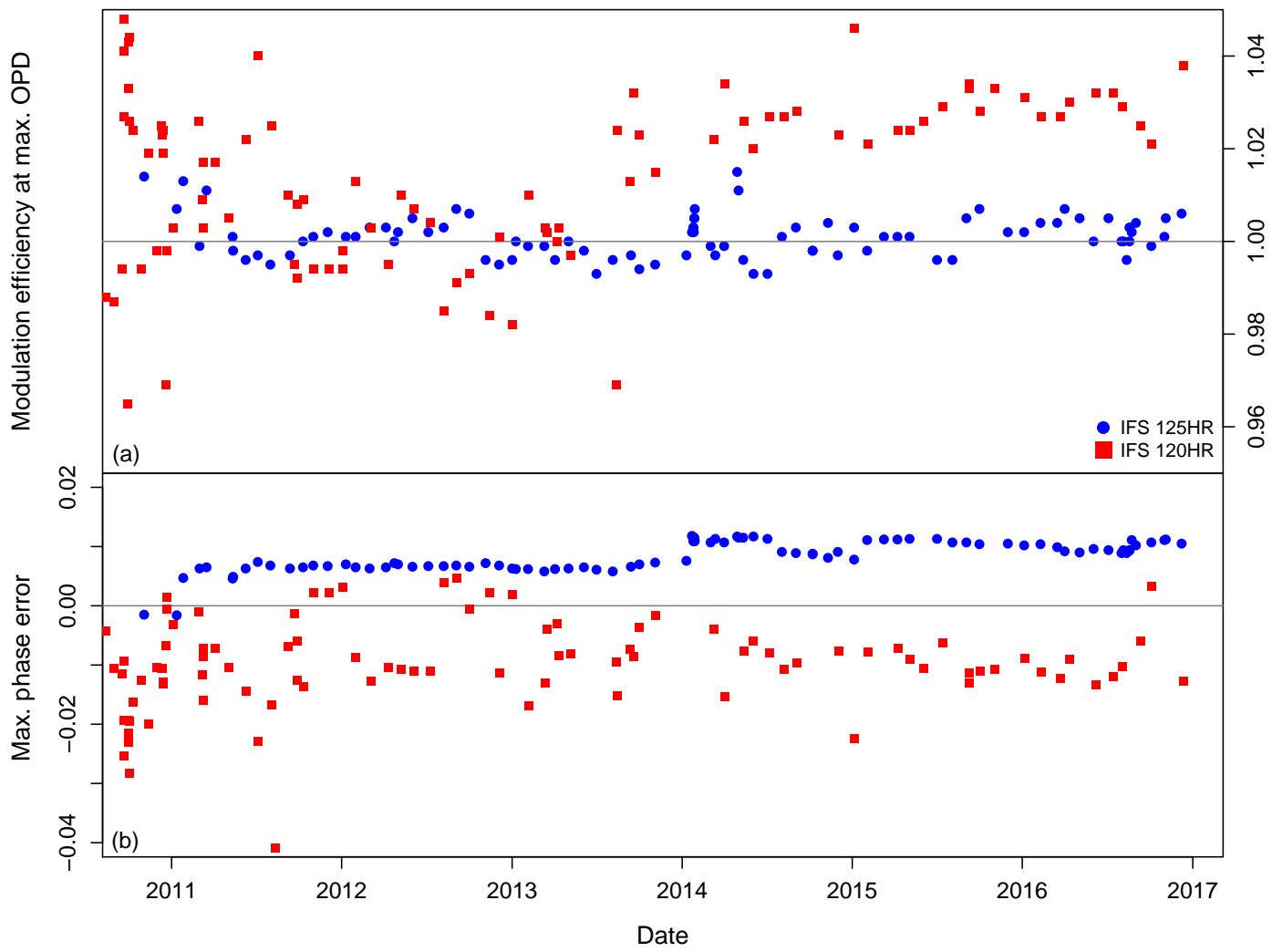

Figure 2. The time series of retrieved modulation efficiencies at $45 \mathrm{~cm}$ optical path difference (a) and maximum phase error (b) for the Bruker IFS120HR and IFS125HR instruments at Lauder, based on lamp measurements of a $10 \mathrm{~cm} \mathrm{HCl}$ cell, indicating the improved stability of the IFS125HR instrument line shape over time.

as these are scaled by the retrieved column of $\mathrm{O}_{2}$ in order to remove such instrumental artefacts. However, the values of $X_{\text {air }}$ that are retrieved and used as a diagnostic and quality indicator within TCCON are perturbed, as in this case it is the theoretical column of dry air that is scaled by the retrieved $\mathrm{O}_{2}$ column. By artificially introducing a timing error into retrievals that are known to have accurate timing, it has been shown that for a timing error of $60 \mathrm{~s}$ and a SZA less than $85^{\circ}$, the perturbation of $X_{\mathrm{CO}_{2}}$ is less than $0.02 \%$, compared to $1 \%$ for $X_{\text {air }}$. Therefore, for the 2014 TCCON data release, data subject to these errors have been included without any attempt to correct them.

\subsection{Time series of $X_{\text {air }}$}

As noted previously, for an ideal retrieval, $X_{\text {air }}$ would be unity, but due to spectroscopic limitations there is a TCCON wide bias and SZA dependence. These are, however, stable both temporally and across the network. Thus, $X_{\text {air }}$ is a useful diagnostic of the quality of measurements, with retrievals deviating more than $1 \%$ from the nominal value of 0.98 indicating systematic errors, e.g. the timing errors mentioned above, or deviations from an ideal ILS.
Figure 3 shows the time series of $X_{\text {air }}$ retrievals from the IFS $125 \mathrm{HR}$ instrument that have satisfied the data quality criteria for release to the TCCON archive. It can be seen that most of these values fall within $1 \%$ of 0.98 (indicated by the dashed lines); however, there are some periods with values outside of these limits, which have been identified as having timing errors. These periods are highlighted in green and defined in Table 2.

In Fig. 4 we show the hourly mean and SD (upper panel) of $X_{\text {air }}$ values for the entire Lauder TCCON dataset covering both instruments.

There is a discontinuity in the SD of the hourly mean time series corresponding to a change from performing retrievals using 10 co-added interferograms sampled at a scanner velocity of $20 \mathrm{kHz}$ to single scans at $40 \mathrm{kHz}$ in May 2006. The discontinuity in both the mean and SD that occurs in early 2010 indicates the change from the IFS 120HR to the IFS $125 \mathrm{HR}$ and demonstrates the improvement in performance with the newer instrument.

\section{Airborne calibration}

The accuracy of TCCON measurements is limited by the available spectral line parameters to around $2-3 \%$. However, 


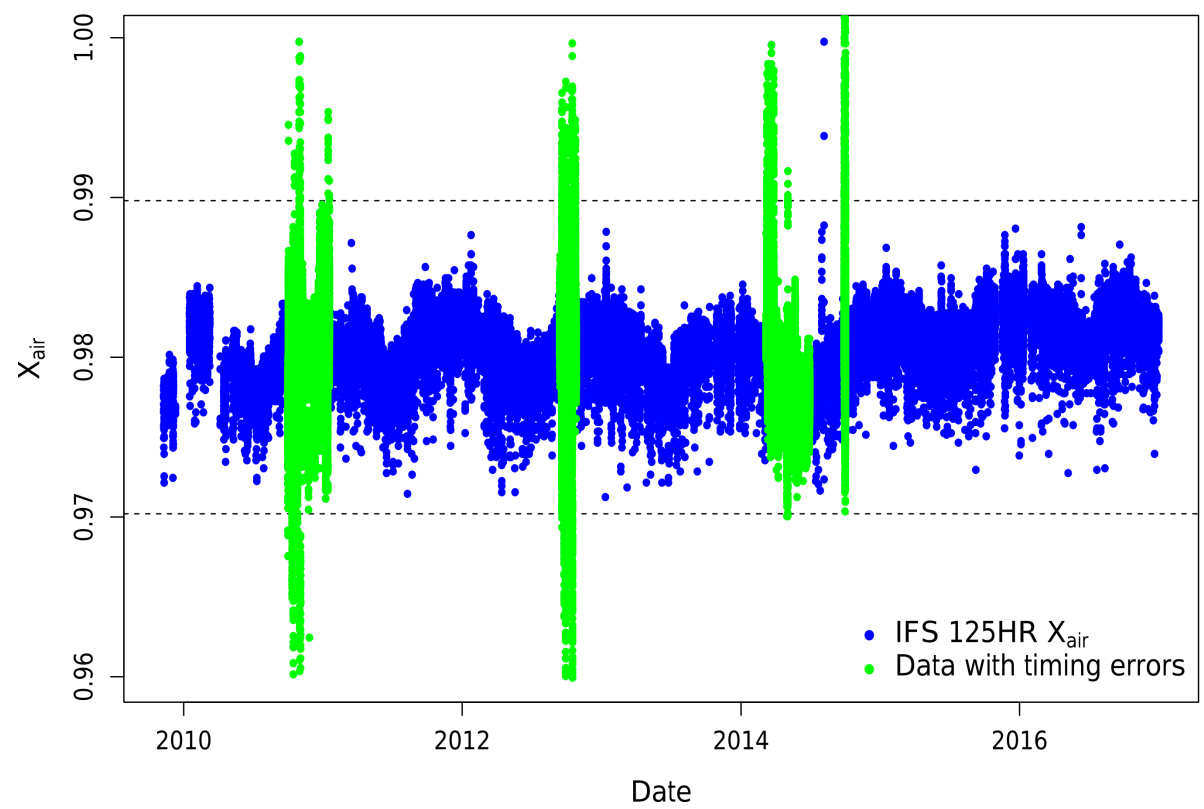

Figure 3. Time series of IFS $125 \mathrm{HR} X_{\text {air }}$. Data affected by timing errors are shown in green and defined in Table 2 . For values not affected by timing errors, only every 10 th data point is plotted for clarity.

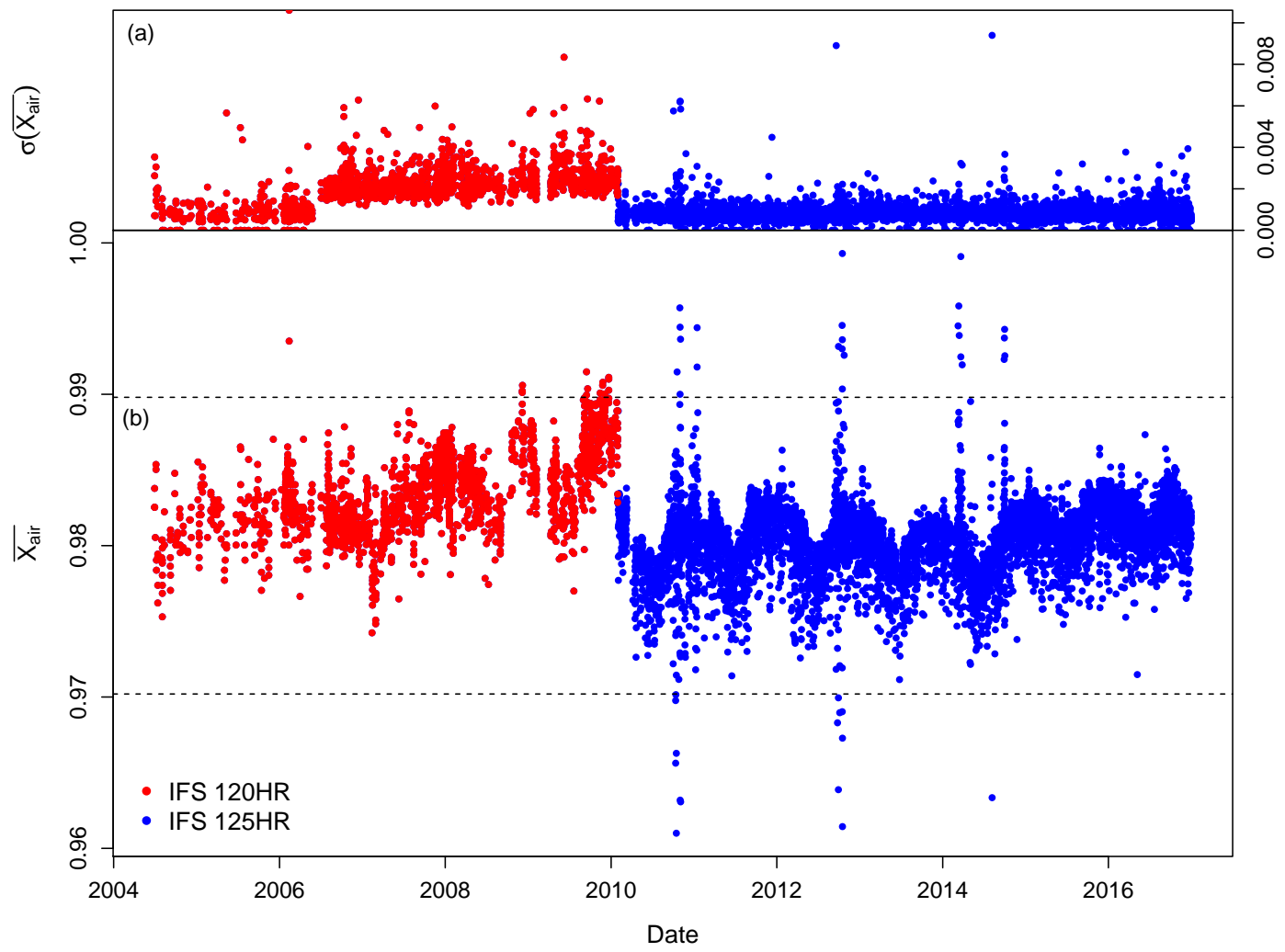

Figure 4. Time series of hourly means of $X_{\text {air }}(\mathbf{b})$ and SDs about them (a) retrieved from measurements made with both FTS instruments at Lauder. 
Table 4. Comparison of airborne calibration scale factors, derived from Lauder flights, with TCCON network-wide values.

\begin{tabular}{lccc}
\hline Species & TCCON scale factor & $120 \mathrm{HR}$ & $125 \mathrm{HR}$ \\
\hline$X_{\mathrm{CO}_{2}}$ & $0.9898 \pm 0.0010$ & $0.9880 \pm 0.0041$ & $0.9911 \pm 0.0014$ \\
$X_{\mathrm{CH}_{4}}$ & $0.9765 \pm 0.0020$ & $0.9879 \pm 0.0052$ & $0.9867 \pm 0.0016$ \\
$X_{\mathrm{CO}}$ & $1.0672 \pm 0.0200$ & $1.0124 \pm 0.1419$ & $0.9655 \pm 0.1116$ \\
$X_{\mathrm{N}_{2} \mathrm{O}}$ & $0.9638 \pm 0.0100$ & $0.9833 \pm 0.0130$ & $0.9809 \pm 0.0081$ \\
\hline
\end{tabular}

because of the use of a common retrieval system across the network, the resulting bias is consistent for all retrievals and sites.

In order to align TCCON measurements with the accepted WMO gas standard scale, a number of in situ, airborne profile measurements have been made at many of the TCCON sites, including Lauder, to derive a network-wide scaling factor for a subset of retrieved species (Wunch et al., 2010). In this section we compare the network wide scaling factors with those derived for the two Lauder instruments.

The Lauder site was included in the flight schedule of each of the HIAPER Pole-to-Pole Observations (HIPPO) campaigns (Wofsy, 2011), and in 2015 it was the base for an AirCore (Karion et al., 2010) campaign. Details of successful calibration flights are listed in Table 3. Each flight consists of one or more altitude profiles that have been averaged together to give measured profiles of the mole fractions of each target species. In some cases operational requirements meant that these profiles could not be performed directly over Lauder and were instead carried out during the approach into, or climb out of, Christchurch International Airport approximately $285 \mathrm{~km}$ to the northeast. It is considered that for the target species, the spatial variability is sufficiently small that these profiles can be considered representative of the air mass at the TCCON site if the boundary layer is discarded. In order to extend the profiles from their lowest level to the surface, they are interpolated using mole fractions measured from surface flask samples collected at the time of overflight at Lauder. Above the maximum altitude attained during the flight, these profiles have been supplemented using the TCCON a priori profiles.

In order to derive DMFs that can be directly compared to the TCCON measurements, the airborne profiles are integrated following the method of Rodgers and Connor (2003), as it was applied by Wunch et al. (2010), weighting with the FTS retrieval averaging kernels to give a smoothed columnaverage DMF $x_{\mathrm{s}}$ :

$x_{\mathrm{s}}=x_{\mathrm{a}}+A\left(x_{\mathrm{h}}-x_{\mathrm{a}}\right)$,

where $x_{\mathrm{a}}$ is the a priori column DMF, $x_{\mathrm{h}}$ is the DMF of the merged aircraft profile and $A$ is the column-averaging kernel.

Figure 5 shows the resulting calibration curves for the smoothed airborne DMFs and the mean of the corresponding day's FTS retrievals for the four species compared. Uncertainties in the airborne measurements are assigned as in
Table 5. Comparison of retrievals from both instruments. Mean difference (IFS 120HR minus IFS 125HR) of daily mean values, their SD and standard error (SD of the sample mean) expressed as a percentage, and the number of daily means compared.

\begin{tabular}{lrrrr}
\hline Species & Mean difference \% & SD & SE & $N$ \\
\hline$X_{\mathrm{CO}_{2}}$ & 0.068 & 0.113 & 0.015 & 55 \\
$X_{\mathrm{CH}_{4}}$ & -0.069 & 0.141 & 0.019 & 55 \\
$X_{\mathrm{CO}}$ & 1.143 & 1.498 & 0.202 & 55 \\
$X_{\mathrm{N}_{2} \mathrm{O}}$ & -0.005 & 0.237 & 0.032 & 55 \\
$X_{\mathrm{H}_{2} \mathrm{O}}$ & 0.684 & 1.555 & 0.210 & 55 \\
$X_{\mathrm{HDO}}$ & 0.666 & 1.917 & 0.258 & 55 \\
$X_{\mathrm{HF}}$ & -0.867 & 0.784 & 0.106 & 55 \\
\hline
\end{tabular}

Wunch et al. (2010), and those for the TCCON measurements are the SD of the day's retrievals. Calibration scaling factors are then calculated assuming a linear relationship, forced through the origin and taking account of the uncertainties in both the smoothed aircraft and TCCON values. The resulting scaling factors for the Lauder instruments and those derived for the entire TCCON network in Wunch et al. (2010), updated in Wunch et al. (2015), are listed in Table 4 . These show good agreement and the accuracy, based on the uncertainty in the fitted linear relationship, following this correction is $0.1 \%$ for $X_{\mathrm{CO}_{2}}$.

\section{Results}

\subsection{Instrument intercomparison}

In order to assess any biases between the two instruments used to collect TCCON data at Lauder, we have compared days on which measurements were taken with both instruments between October 2009 and December 2012. Figures 6 to 8 show in the upper panels the daily mean retrieved values for $X_{\mathrm{CO}_{2}}, X_{\mathrm{CH}_{4}}$ and $X_{\mathrm{CO}}$ respectively. Error bars represent the SD about the daily means. The lower panels show the difference (IFS 120HR - IFS 125HR) between the daily means, and the error bars are the sum in quadrature of the SDs about the daily means. Also plotted are the mean of the daily mean differences and the associated SD and standard error. These values are listed as percentages for all compared species in Table 5. For $X_{\mathrm{CO}_{2}}$ the mean bias is $0.068 \%$ with a standard error of $0.015 \%$. 

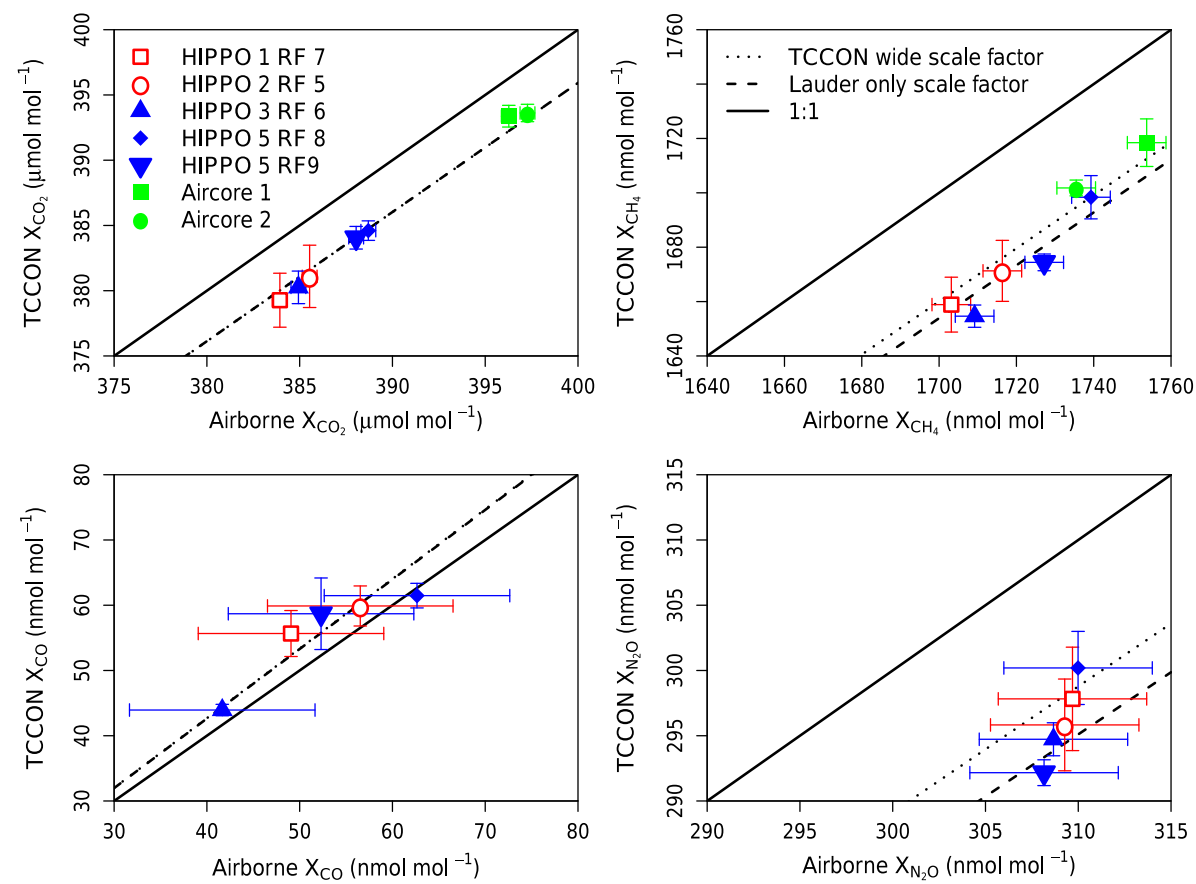

Figure 5. Airborne calibration curves for $X_{\mathrm{CO}_{2}}, X_{\mathrm{CH}_{4}}, X_{\mathrm{CO}}$ and $X_{\mathrm{N}_{2} \mathrm{O}}$ with fitted linear relationships derived for the TCCON network and Lauder-only intercomparisons (forced through origin). The HIPPO 1 and 2 flights were compared to the IFS 120HR (open symbols); all others were compared to the IFS 125HR (filled symbols).

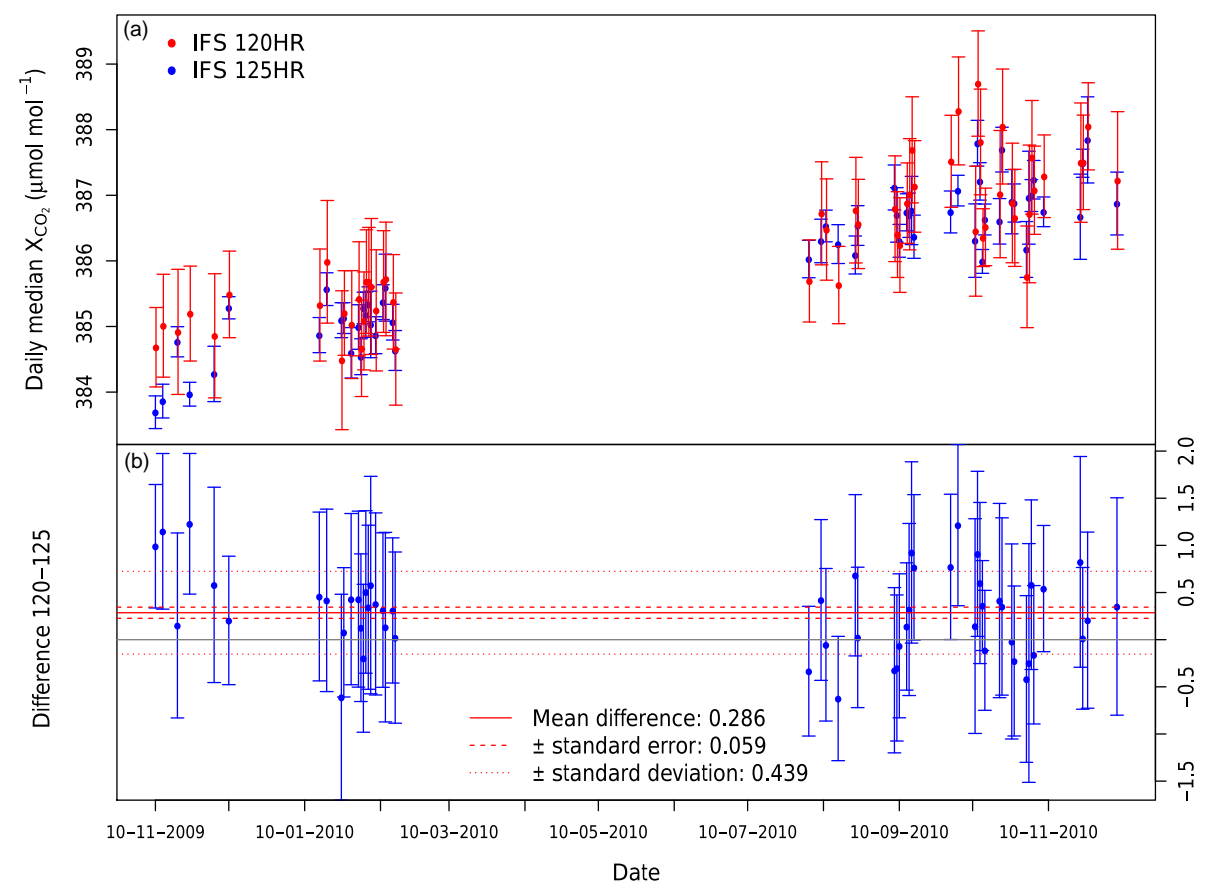

Figure 6. Time series of daily means of retrieved $X_{\mathrm{CO}_{2}}$ from measurements made with both FTS instruments at Lauder (a) and the difference between them (b). Error bars in the upper panel indicate the SD about the daily mean, while those in the lower panel are the sum in quadrature of the SD about the daily means. The horizontal lines in the lower panel show the mean of the daily mean differences and the SD and standard error (SD of the sample mean) about it. 


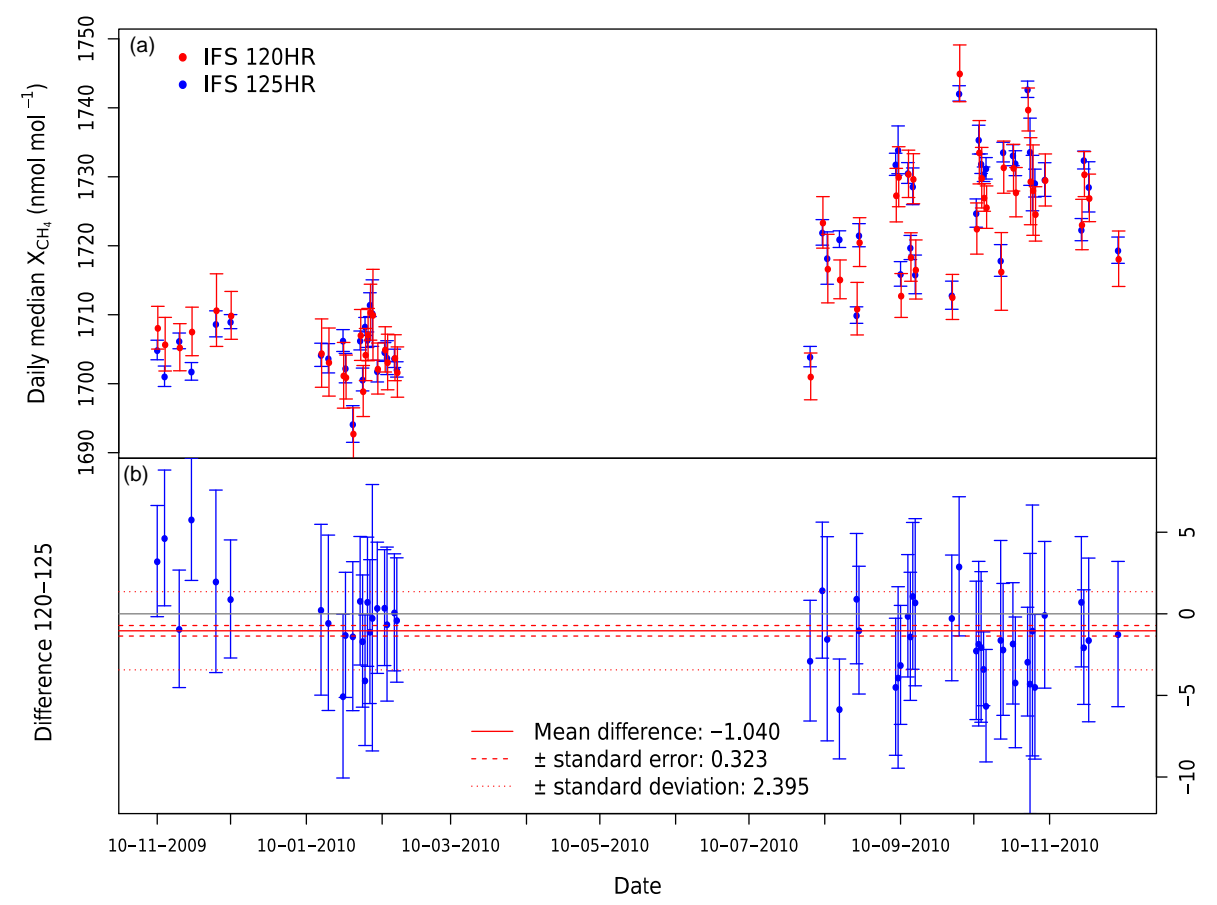

Figure 7. As Fig. 6 but for $X_{\mathrm{CH}_{4}}$.

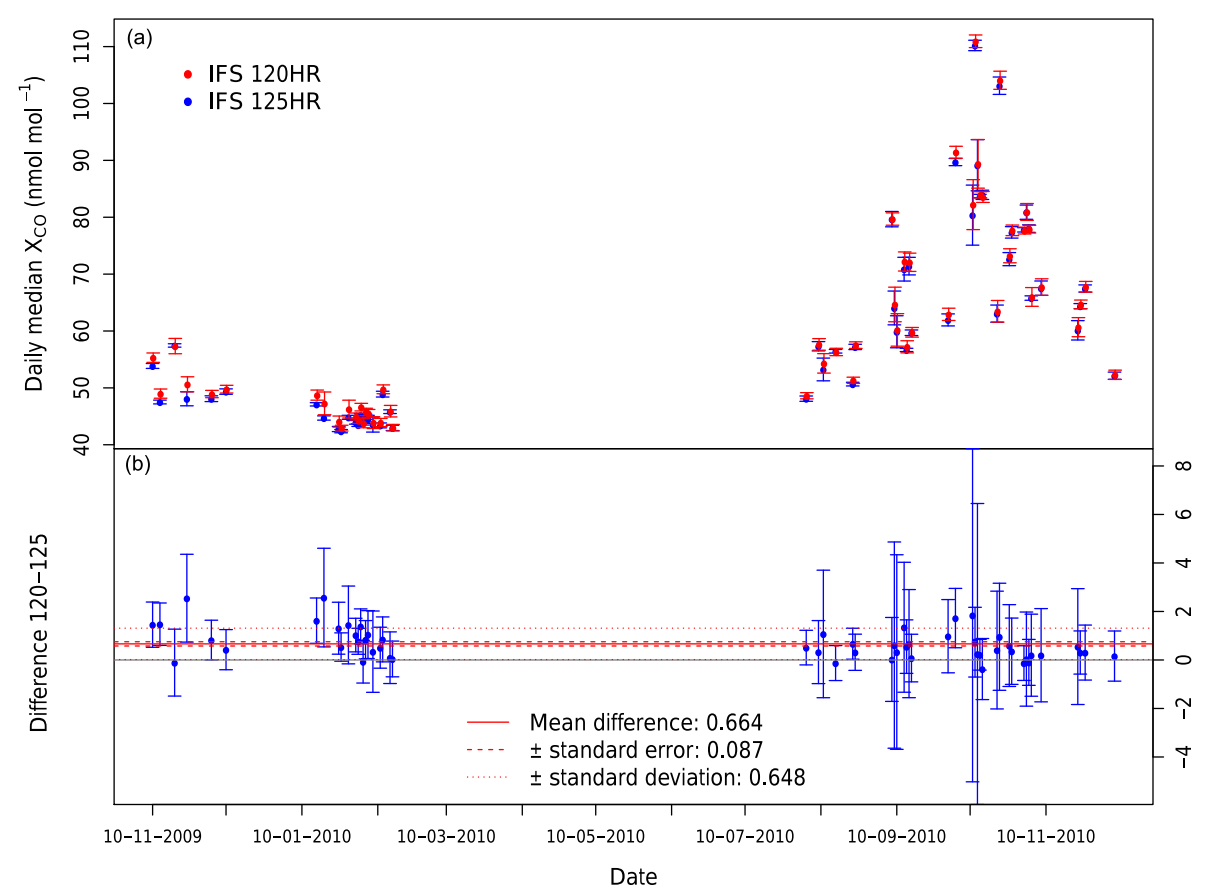

Figure 8. As Fig. 6 but for $X_{\mathrm{CO}}$.

\subsection{Time series of retrieved species}

Here we present a subset of retrieval time series available in the Lauder TCCON data archive. Figures 9 to 11 show the hourly means of the retrieved $X_{\text {gas }}$, along with their SD in the upper panels. These figures are made up of data from both of the Lauder instruments with the change-over occurring on 1 February 2010.

The time series of $X_{\mathrm{CO}_{2}}$ values is shown in Fig. 9. Over the length of this time series $X_{\mathrm{CO}_{2}}$ has been increasing by approximately $2 \mu \mathrm{mol} \mathrm{mol}^{-1} \mathrm{yr}^{-1}$. There is a seasonal cy- 


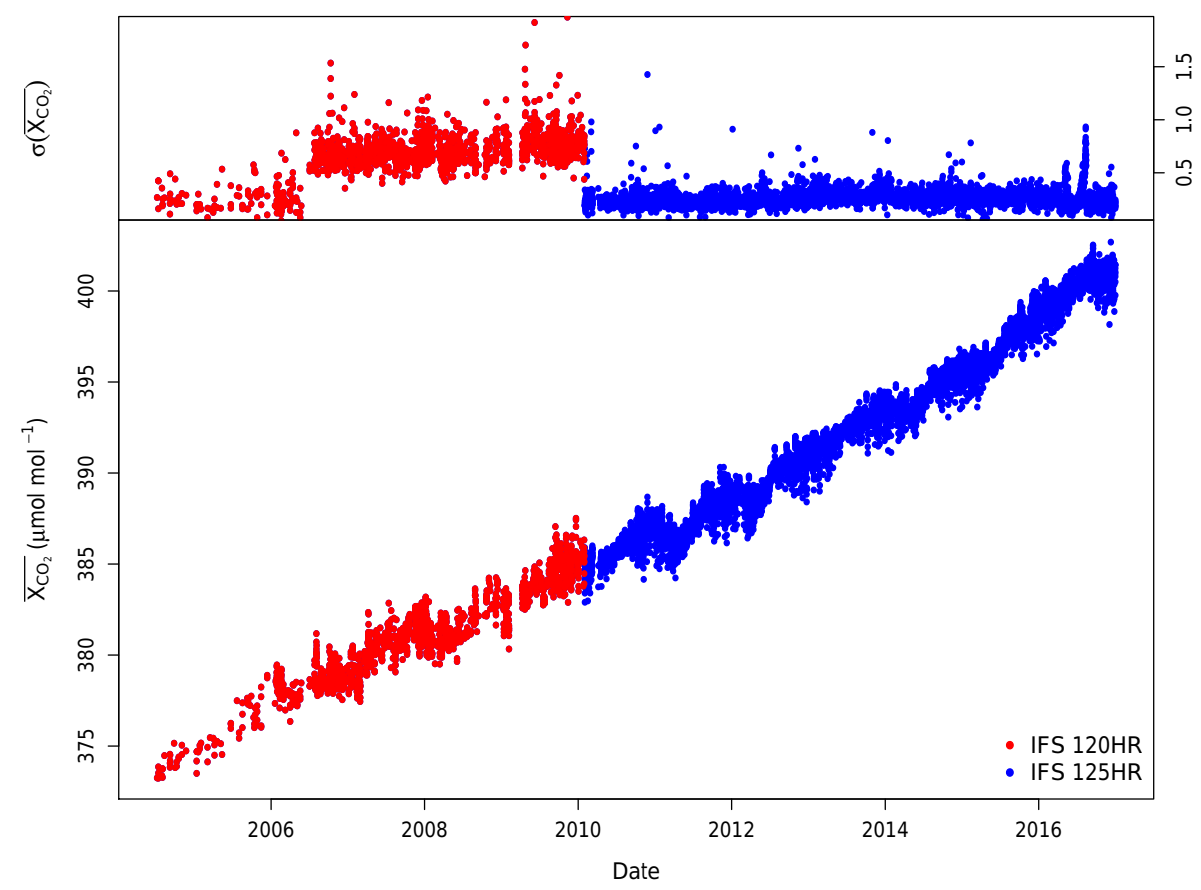

Figure 9. Time series of hourly means of $X_{\mathrm{CO}_{2}}$ retrieved from measurements made with both FTS instruments at Lauder.

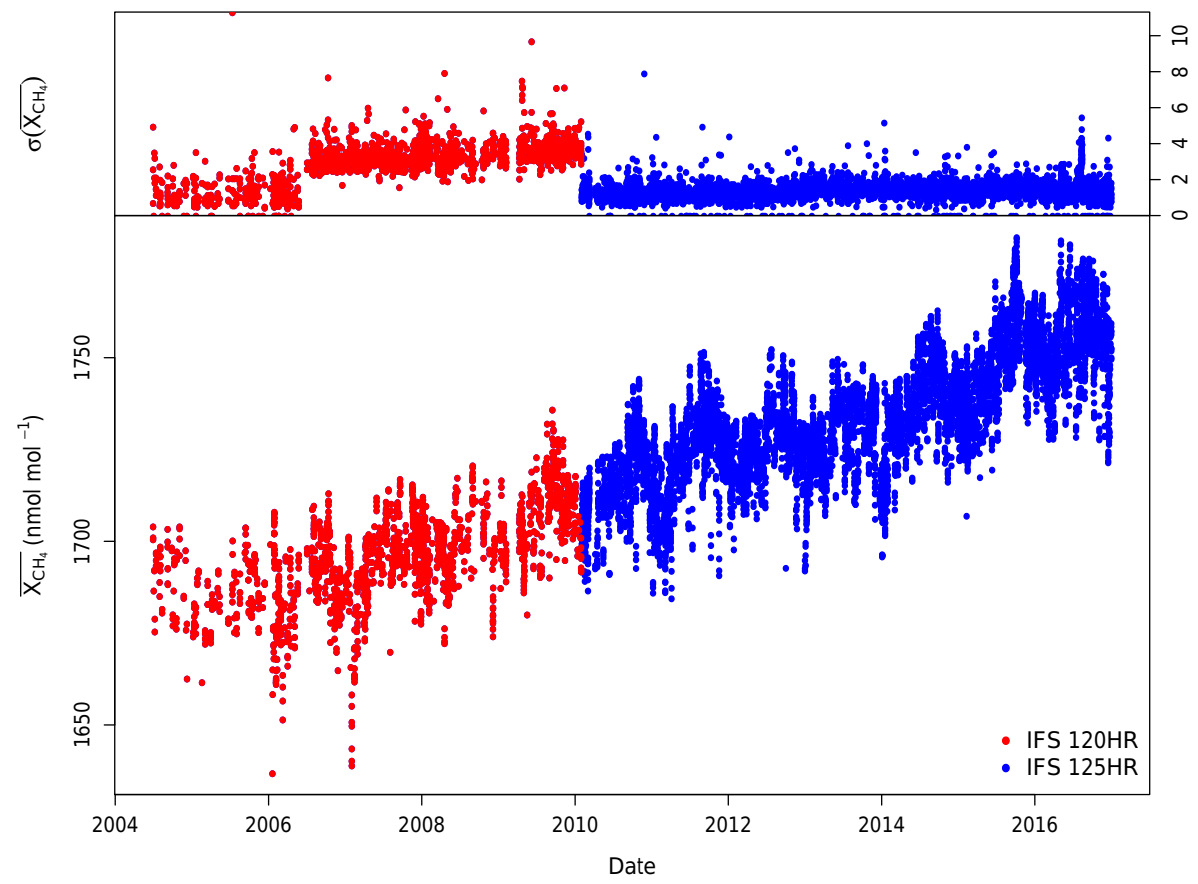

Figure 10. Time series of hourly means of $X_{\mathrm{CH}_{4}}$ retrieved from measurements made with both FTS instruments at Lauder.

cle due to summer drawdown, but it is smaller than in the Northern Hemisphere (Deutscher et al., 2014). Since measurements using the IFS 125HR began, the SD about the hourly mean has been better than $0.1 \%$ for $96.81 \%$ of re- trievals and better than $0.25 \%$ for $99.96 \%$ of retrievals. The precision of the IFS $120 \mathrm{HR}$ was poorer, with only $14.95 \%$ of hourly SDs better than 0.1 and $95.93 \%$ better than $0.25 \%$. 


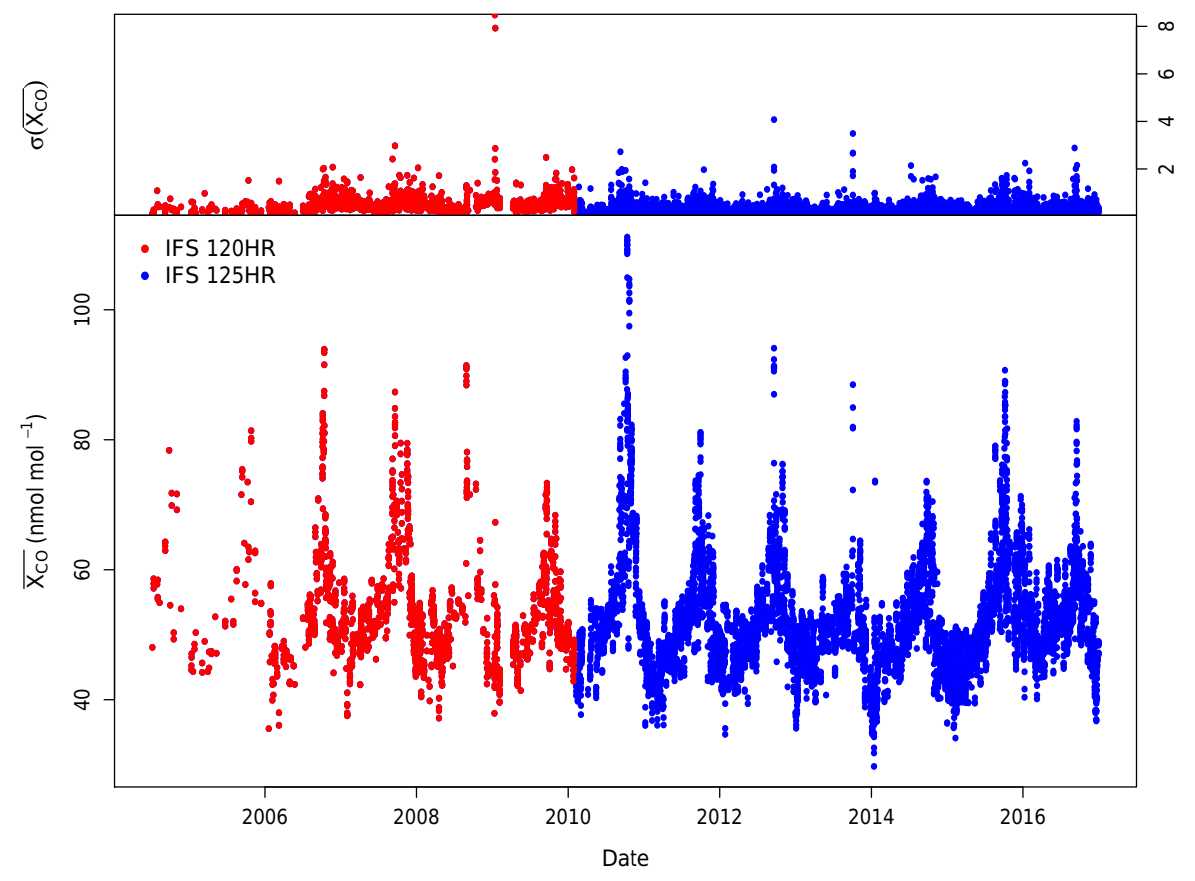

Figure 11. Time series of hourly means of $X_{\mathrm{CO}}$ retrieved from measurements made with both FTS instruments at Lauder.

Table 6. Precision of Lauder $X_{\mathrm{CO}_{2}}$ datasets compared to TCCON targets.

\begin{tabular}{lrr}
\hline Instrument & IFS $120 \mathrm{HR}$ & IFS $125 \mathrm{HR}$ \\
\hline Mean SD about hourly means & $0.17 \%$ & $0.07 \%$ \\
$\%<0.25 \%$ & 95.93 & 99.96 \\
$\%<0.1 \%$ & 14.95 & 96.81 \\
\hline
\end{tabular}

The precision of both instruments compared to the TCCON targets are shown in Table 6.

Figure 10 shows the $X_{\mathrm{CH}_{4}}$ time series. $X_{\mathrm{CH}_{4}}$ has a smaller positive trend of approximately $5.6 \mathrm{nmol} \mathrm{mol}^{-1} \mathrm{yr}^{-1}$ and a seasonal cycle of similar magnitude with a summer minimum due to oxidation by photochemically produced $\mathrm{OH}$ radicals. The Lauder TCCON $X_{\mathrm{CH}_{4}}$ time series starts around 2 years before the end of a period of stable atmospheric $\mathrm{CH}_{4}$ concentrations that has been observed in a number of different time series (Schaefer et al., 2016, and references therein) and this is also apparent in the data shown here.

The time series of $X_{\mathrm{CO}}$ shown in Fig. 11 has a small, negative trend and a stronger seasonal cycle with a summer minimum due to $\mathrm{OH}$ oxidation and a springtime peak attributed to $\mathrm{CO}$ transported from Southern Hemisphere biomass burning sources (Buchholz et al., 2016).

Figure 12 shows the time series of the remaining retrieved species.

\section{Data availability}

The GGG2014 versions of the processed Lauder TCCON data are available from the TCCON data archive (Sherlock et al., 2014a, b). The data DOIs are https://doi.org/10.14291/tccon.ggg2014.lauder01.R0/1149293 for the IFS 120HR data and https://doi.org/10.14291/tccon.ggg2014.lauder02.R0/1149298 for the IFS $125 \mathrm{HR}$ data.

The IFS 120HR data are available from 20 June 2004 to 28 February 2010, while the IFS $125 \mathrm{HR}$ data cover the range 2 February 2010 to the present day, with data becoming publicly available 180 days after collection.

\section{Conclusions}

The Lauder TCCON dataset contains retrievals of $X_{\mathrm{CO}_{2}}$, $X_{\mathrm{CH}_{4}}, X_{\mathrm{N}_{2} \mathrm{O}}, X_{\mathrm{HF}}, X_{\mathrm{H}_{2} \mathrm{O}}, X_{\mathrm{HDO}}$ and $X_{\mathrm{CO}}$ from June 2004 to the present date using two FTS instruments. Overlapping measurements were made using both instruments and from these, the bias between them was assessed to be $0.068 \%$ for $X_{\mathrm{CO}_{2}}$. Regular monitoring of the ILS (monthly, both instruments) and LSE (quarterly, IFS 125HR only) is carried out to ensure the consistent performance of the instruments and the quality of the retrievals and to achieve the TCCON target precision of $0.1 \%$ for $X_{\mathrm{CO}_{2}}$ as well as consistency with the rest of the network.

Airborne calibration campaigns have shown that the scale factors required to align the Lauder retrievals of $X_{\mathrm{CO}_{2}}, X_{\mathrm{CH}_{4}}$, 


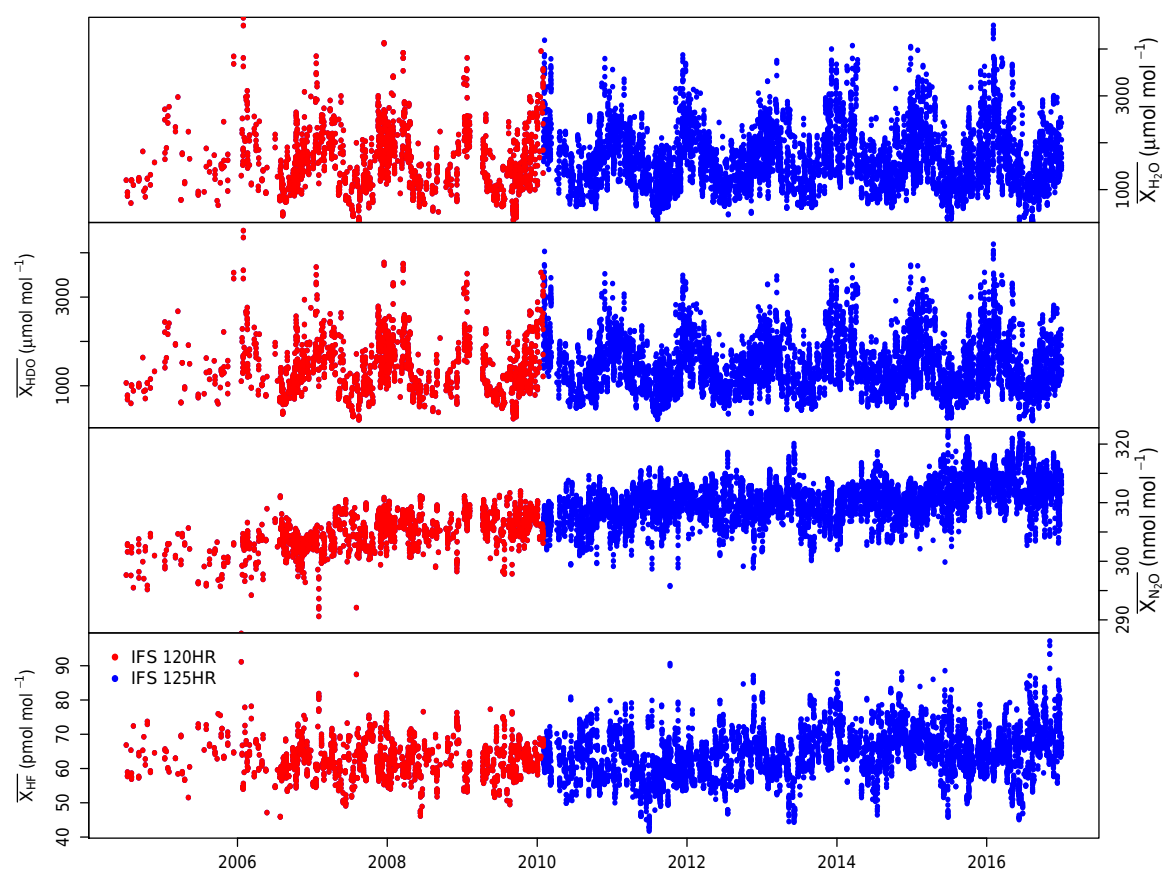

Figure 12. Time series of hourly means of $X_{\mathrm{H}_{2} \mathrm{O}}(\mathbf{a}), X_{\mathrm{HDO}}(\mathbf{b}), X_{\mathrm{N}_{2} \mathrm{O}}(\mathbf{c})$ and $X_{\mathrm{HF}}(\mathbf{d})$ retrieved from measurements made with both FTS instruments at Lauder.

$X_{\mathrm{CO}}$ and $X_{\mathrm{N}_{2} \mathrm{O}}$ with WMO scales are consistent with those used across the TCCON.

Timing errors have sporadically affected measurements taken with the IFS $125 \mathrm{HR}$ instrument, which have perturbed the retrieved values for $X_{\text {air }}$ by up to $2 \%$. However, due to the scaling by the co-retrieved column of $\mathrm{O}_{2}$, the effect on retrievals of other gases has been minimal, less than $0.02 \%$ in the case of $\mathrm{CO}_{2}$ at SZAs less than $85^{\circ}$. In a future data release it is expected that these timing errors will be retrospectively corrected.

Author contributions. BC was the instigator of the Lauder TCCON programme and was the Lauder TCCON principal investigator (PI) until 2008. VS was involved in the early development of the Lauder TCCON project and was the site PI from 2008 to 2014. VS was responsible for the retrieval of the TCCON products from the Lauder spectra. JR is responsible for the operation and alignment of the FTS instruments and developed the NIWA solar trackers. ND analysed the air mass dependence and provided advice on data processing and methods for carrying out airborne calibrations. HS maintains the GGG processing system (developed by VS) and quality control of the TCCON data products. DP is the current TCCON site PI for Lauder and wrote this paper. All authors have read and provided feedback on the paper.

Competing interests. The authors declare that they have no conflict of interest.
Acknowledgements. The Lauder TCCON programme is corefunded by NIWA through New Zealand's Ministry of Business, Innovation and Employment with additional support from the $\mathrm{Na}$ tional Institute for Environmental Studies, Japan, GOSAT project.

Nicholas Deutscher is supported by an Australian Research Council - Discovery Early Career Researcher Award DE140100178.

The authors would like to acknowledge the following: Colm Sweeney, Sonja Wolter, Tim Newberger and Jack Higgs of NOAA in organising the AirCore campaign at Lauder and the logistical support of Richard Querel, Wills Dobson, Jocelyn Turnbull and Joel Wilson during the AirCore flights; Steve Wofsy and Britt Stevens for providing calibrated HIPPO data; Paul Wennberg, Debra Wunch, and Coleen Roehl of Caltech and Geoff Toon of JPL for technical and hardware assistance over the years; and Dan Smale and Mike Harvey for the useful and informative discussions and advice.

Edited by: David Carlson

Reviewed by: two anonymous referees

\section{References}

Bergland, G. D.: A radix-eight fast Fourier transform subroutine for real-valued series, IEEE T. Acoust. Speech, 17, 138-144, https://doi.org/10.1109/tau.1969.1162043, 1969.

Brailsford, G. W., Stephens, B. B., Gomez, A. J., Riedel, K., Mikaloff Fletcher, S. E., Nichol, S. E., and Manning, M. R.: Long-term continuous atmospheric $\mathrm{CO}_{2}$ measurements at Bar- 
ing Head, New Zealand, Atmos. Meas. Tech., 5, 3109-3117, https://doi.org/10.5194/amt-5-3109-2012, 2012.

Buchholz, R. R., Paton-Walsh, C., Griffith, D. W. T., Kubistin, D., Caldow, C., Fisher, J. A., Deutscher, N. M., Kettlewell, G., Riggenbach, M., Macatangay, R., Krummel, P. B., and Langenfelds, R. L.: Source and meteorological influences on air quality $\left(\mathrm{CO}, \mathrm{CH}_{4} \& \mathrm{CO}_{2}\right)$ at a Southern Hemisphere urban site, Atmos. Environ., 126, 274-289, https://doi.org/10.1016/j.atmosenv.2015.11.041, 2016.

Chevallier, F., Deutscher, N. M., Conway, T. J., Ciais, P., Ciattaglia, L., Dohe, S., Fröhlich, M., Gomez-Pelaez, A. J., Griffith, D., Hase, F., Haszpra, L., Krummel, P., Kyrö, E., Labuschagne, C., Langenfelds, R., Machida, T., Maignan, F., Matsueda, H., Morino, I., Notholt, J., Ramonet, M., Sawa, Y., Schmidt, M., Sherlock, V., Steele, P., Strong, K., Sussmann, R., Wennberg, P., Wofsy, S., Worthy, D., Wunch, D., and Zimnoch, M.: Global $\mathrm{CO}_{2}$ fluxes inferred from surface air-sample measurements and from TCCON retrievals of the $\mathrm{CO}_{2}$ total column, Geophys. Res. Lett., 38, L24810, https://doi.org/10.1029/2011GL049899, 2011.

Connor, B. J., Sherlock, V., Toon, G., Wunch, D., and Wennberg, P. O.: GFIT2: an experimental algorithm for vertical profile retrieval from near-IR spectra, Atmos. Meas. Tech., 9, 3513-3525, https://doi.org/10.5194/amt-9-3513-2016, 2016.

Crisp, D., Miller, C. E., and DeCola, P. L.: NASA Orbiting Carbon Observatory: measuring the column averaged carbon dioxide mole fraction from space, J. Appl. Remote Sens., 2, 023508, https://doi.org/10.1117/1.2898457, 2008.

Crisp, D., Fisher, B. M., O’Dell, C., Frankenberg, C., Basilio, R., Bösch, H., Brown, L. R., Castano, R., Connor, B., Deutscher, N. M., Eldering, A., Griffith, D., Gunson, M., Kuze, A., Mandrake, L., McDuffie, J., Messerschmidt, J., Miller, C. E., Morino, I., Natraj, V., Notholt, J., O’Brien, D. M., Oyafuso, F., Polonsky, I., Robinson, J., Salawitch, R., Sherlock, V., Smyth, M., Suto, H., Taylor, T. E., Thompson, D. R., Wennberg, P. O., Wunch, D., and Yung, Y. L.: The ACOS $\mathrm{CO}_{2}$ retrieval algorithm - Part II: Global $X_{\mathrm{CO}_{2}}$ data characterization, Atmos. Meas. Tech., 5, 687707, https://doi.org/10.5194/amt-5-687-2012, 2012.

Deutscher, N. M., Griffith, D. W. T., Bryant, G. W., Wennberg, P. O., Toon, G. C., Washenfelder, R. A., Keppel-Aleks, G., Wunch, D., Yavin, Y., Allen, N. T., Blavier, J.-F., Jiménez, R., Daube, B. C., Bright, A. V., Matross, D. M., Wofsy, S. C., and Park, S.: Total column $\mathrm{CO}_{2}$ measurements at Darwin, Australia - site description and calibration against in situ aircraft profiles, Atmos. Meas. Tech., 3, 947-958, https://doi.org/10.5194/amt-3947-2010, 2010.

Deutscher, N. M., Sherlock, V., Mikaloff Fletcher, S. E., Griffith, D. W. T., Notholt, J., Macatangay, R., Connor, B. J., Robinson, J., Shiona, H., Velazco, V. A., Wang, Y., Wennberg, P. O., and Wunch, D.: Drivers of column-average $\mathrm{CO}_{2}$ variability at Southern Hemispheric Total Carbon Column Observing Network sites, Atmos. Chem. Phys., 14, 9883-9901, https://doi.org/10.5194/acp-14-9883-2014, 2014.

Dupuy, E., Morino, I., Deutscher, N., Yoshida, Y., Uchino, O., Connor, B., De Mazière, M., Griffith, D., Hase, F., Heikkinen, P., Hillyard, P., Iraci, L., Kawakami, S., Kivi, R., Matsunaga, T., Notholt, J., Petri, C., Podolske, J., Pollard, D., Rettinger, M., Roehl, C., Sherlock, V., Sussmann, R., Toon, G., Velazco, V., Warneke, T., Wennberg, P., Wunch, D., and Yokota, T.: Compar- ison of $X_{\mathrm{H}_{2} \mathrm{O}}$ retrieved from GOSAT short-wavelength infrared spectra with observations from the TCCON Network, Remote Sens., 8, 414, https://doi.org/10.3390/rs8050414, 2016.

Griffith, D. W. T., Deutscher, N. M., Caldow, C., Kettlewell, G., Riggenbach, M., and Hammer, S.: A Fourier transform infrared trace gas and isotope analyser for atmospheric applications, Atmos. Meas. Tech., 5, 2481-2498, https://doi.org/10.5194/amt-52481-2012, 2012.

Hase, F., Drouin, B. J., Roehl, C. M., Toon, G. C., Wennberg, P. O., Wunch, D., Blumenstock, T., Desmet, F., Feist, D. G., Heikkinen, P., De Mazière, M., Rettinger, M., Robinson, J., Schneider, M., Sherlock, V., Sussmann, R., Té, Y., Warneke, T., and Weinzierl, C.: Calibration of sealed $\mathrm{HCl}$ cells used for TCCON instrumental line shape monitoring, Atmos. Meas. Tech., 6, 3527-3537, https://doi.org/10.5194/amt-6-3527-2013, 2013.

Kalnay, E., Kanamitsu, M., Kistler, R., Collins, W., Deaven, D., Gandin, L., Iredell, M., Saha, S., White, G., Woollen, J., Zhu, Y., Chelliah, M., Ebisuzaki, W., Higgins, W., Janowiak, J., Mo, K. C., Ropelewski, C., Wang, J., Leetmaa, A., Reynolds, R., Jenne, R., and Joseph, D.: The NCEP/NCAR 40-year reanalysis project, B. Am. Meteorol. Soc. , 77, 437-471, https://doi.org/10.1175/15200477(1996)077<0437:tnyrp>2.0.co;2, 1996.

Karion, A., Sweeney, C., Tans, P., and Newberger, T.: AirCore: an innovative atmospheric sampling system, J. Atmos. Ocean. Tech., 27, 1839-1853, https://doi.org/10.1175/2010JTECHA1448.1, 2010.

Keppel-Aleks, G., Toon, G. C., Wennberg, P. O., and Deutscher, N. M.: Reducing the impact of source brightness fluctuations on spectra obtained by Fouriertransform spectrometry, Appl. Optics, 46, 4774-4779, https://doi.org/10.1364/AO.46.004774, 2007.

Mertz, L.: Auxiliary computation for Fourier spectrometry, Infrared Phys., 7, 17-23, https://doi.org/10.1016/0020-0891(67)90026-7, 1967.

Messerschmidt, J., Macatangay, R., Notholt, J., Petri, C., Warneke, T., and Weinzierl, C.: Side by side measurements of $\mathrm{CO}_{2}$ by ground-based Fourier transform spectrometry (FTS), Tellus B, 62, 749-758, https://doi.org/10.1111/j.16000889.2010.00491.x, 2010.

Olsen, S. C. and Randerson, J. T.: Differences between surface and column atmospheric $\mathrm{CO}_{2}$ and implications for carbon cycle research, J. Geophys. Res.-Atmos., 109, D02301, https://doi.org/10.1029/2003JD003968, 2004.

Rayner, P. J. and O'Brien, D. M.: The utility of remotely sensed $\mathrm{CO}_{2}$ concentration data in surface source inversions, Geophys. Res. Lett., 28, 175-178, https://doi.org/10.1029/2000GL011912, 2001.

Rodgers, C. D. and Connor, B. J.: Intercomparison of remote sounding instruments, J. Geophys. Res.-Atmos., 108, 4116-4229, https://doi.org/10.1029/2002jd002299, 2003.

Rothman, L. S., Gordon, I. E., Babikov, Y., Barbe, A., Benner, D. C., Bernath, P. F., Birk, M., Bizzocchi, L., Boudon, V., Brown, L. R., Campargue, A., Chance, K., Cohen, E. A., Coudert, L. H., Devi, V. M., Drouin, B. J., Fayt, A., Flaud, J. M., Gamache, R. R., Harrison, J. J., Hartmann, J. M., Hill, C., Hodges, J. T., Jacquemart, D., Jolly, A., Lamouroux, J., Le Roy, R. J., Li, G., Long, D. A., Lyulin, O. M., Mackie, C. J., Massie, S. T., Mikhailenko, S., Muller, H. S. P., Nau- 
menko, O. V., Nikitin, A. V., Orphal, J., Perevalov, V., Perrin, A., Polovtseva, E. R., Richard, C., Smith, M. A. H., Starikova, E., Sung, K., Tashkun, S., Tennyson, J., Toon, G. C., Tyuterev, V. G., and Wagner, G.: The HITRAN2012 molecular spectroscopic database, J. Quant. Spectrosc. Ra., 130, 4-50, https://doi.org/10.1016/j.jqsrt.2013.07.002, 2013.

Schaefer, H., Fletcher, S. E. M., Veidt, C., Lassey, K. R., Brailsford, G. W., Bromley, T. M., Dlugokencky, E. J., Michel, S. E., Miller, J. B., Levin, I., Lowe, D. C., Martin, R. J., Vaughn, B. H., and White, J. W. C.: A 21st-century shift from fossil-fuel to biogenic methane emissions indicated by ${ }^{13} \mathrm{CH}_{4}$, Science, 352, 8084, https://doi.org/10.1126/science.aad2705, 2016.

Schepers, D., Butz, A., Hu, H., Hasekamp, O. P., Arnold, S. G., Schneider, M., Feist, D. G., Morino, I., Pollard, D., Aben, I., and Landgraf, J.: Methane and carbon dioxide total column retrievals from cloudy GOSAT soundings over the oceans, J. Geophys. Res.-Atmos., 121, 5031-5050, https://doi.org/10.1002/2015JD023389, 2016.

Sherlock, V., Connor, B., Robinson, J., Shiona, H., Smale, D., and Pollard, D.: TCCON data from Lauder, New Zealand, 120HR, Release GGG2014R0, https://doi.org/10.14291/tccon.ggg2014.lauder01.R0/1149293,

TCCON data archive, hosted by the Carbon Dioxide Information Analysis Center, Oak Ridge National Laboratory, Oak Ridge, Tennessee, USA, 2014a.

Sherlock, V., Connor, B., Robinson, J., Shiona, H., Smale, D., and Pollard, D.: TCCON data from Lauder, New Zealand, 125HR, Release GGG2014R0, https://doi.org/10.14291/tccon.ggg2014.lauder02.R0/1149298,

TCCON data archive, hosted by the Carbon Dioxide Information Analysis Center, Oak Ridge National Laboratory, Oak Ridge, Tennessee, USA, 2014b.

Steinkamp, K., Mikaloff Fletcher, S. E., Brailsford, G., Smale, D., Moore, S., Keller, E. D., Baisden, W. T., Mukai, H., and Stephens, B. B.: Atmospheric $\mathrm{CO}_{2}$ observations and models suggest strong carbon uptake by forests in New Zealand, Atmos. Chem. Phys., 17, 47-76, https://doi.org/10.5194/acp-17-472017, 2017.

Toon, G. C.: Telluric line list for GGG2014, available at: https://doi.org/10.14291/tccon.ggg2014.atm.R0/1221656, last access: 2 May 2014a.

Toon, G. C.: Solar line list for GGG2014, available at: https://doi.org/10.14291/tccon.ggg2014.solar.R0/1221658, last access: 2 May 2014b.

Toon, G. C. and Wunch, D.: A stand-alone a priori profile generation tool for GGG2014, available at: https://doi.org/10.14291/tccon.ggg2014.priors.R0/1221661 (last access: 15 June 2016), 2014.

Wofsy, S. C.: HIAPER Pole-to-Pole Observations (HIPPO): finegrained, global-scale measurements of climatically important atmospheric gases and aerosols, Philos. T. R. Soc. A, 369, 20732086, https://doi.org/10.1098/rsta.2010.0313, 2011.

Wunch, D., Toon, G. C., Wennberg, P. O., Wofsy, S. C., Stephens, B. B., Fischer, M. L., Uchino, O., Abshire, J. B., Bernath, P., Biraud, S. C., Blavier, J.-F. L., Boone, C., Bowman, K. P., Browell, E. V., Campos, T., Connor, B. J., Daube, B. C., Deutscher, N. M., Diao, M., Elkins, J. W., Gerbig, C., Gottlieb, E., Griffith, D. W. T., Hurst, D. F., Jiménez, R., Keppel-Aleks, G., Kort, E. A., Macatangay, R., Machida, T., Matsueda, H., Moore, F.,
Morino, I., Park, S., Robinson, J., Roehl, C. M., Sawa, Y., Sherlock, V., Sweeney, C., Tanaka, T., and Zondlo, M. A.: Calibration of the Total Carbon Column Observing Network using aircraft profile data, Atmos. Meas. Tech., 3, 1351-1362, https://doi.org/10.5194/amt-3-1351-2010, 2010.

Wunch, D., Toon, G. C., Blavier, J. F. L., Washenfelder, R. A., Notholt, J., Connor, B. J., Griffith, D. W. T., Sherlock, V., and Wennberg, P. O.: The Total Carbon Column Observing Network, Philos. T. R. Soc. A, 369, 2087-2112, https://doi.org/10.1098/rsta.2010.0240, 2011a.

Wunch, D., Wennberg, P. O., Toon, G. C., Connor, B. J., Fisher, B., Osterman, G. B., Frankenberg, C., Mandrake, L., O’Dell, C., Ahonen, P., Biraud, S. C., Castano, R., Cressie, N., Crisp, D., Deutscher, N. M., Eldering, A., Fisher, M. L., Griffith, D. W. T., Gunson, M., Heikkinen, P., Keppel-Aleks, G., Kyrö, E., Lindenmaier, R., Macatangay, R., Mendonca, J., Messerschmidt, J., Miller, C. E., Morino, I., Notholt, J., Oyafuso, F. A., Rettinger, M., Robinson, J., Roehl, C. M., Salawitch, R. J., Sherlock, V., Strong, K., Sussmann, R., Tanaka, T., Thompson, D. R., Uchino, O., Warneke, T., and Wofsy, S. C.: A method for evaluating bias in global measurements of $\mathrm{CO}_{2}$ total columns from space, Atmos. Chem. Phys., 11, 12317-12337, https://doi.org/10.5194/acp-11-12317-2011, $2011 \mathrm{~b}$.

Wunch, D., Toon, G., Sherlock, V., Deutscher, N. M., Liu, C., Feist, D. G., and Wennberg, P. O.: The Total Carbon Column Observing Network's GGG2014 Data Version, available at: https://doi.org/10.14291/tccon.ggg2014.documentation.R0/1221662, last access: 16 December 2015.

Wunch, D., Wennberg, P. O., Osterman, G., Fisher, B., Naylor, B., Roehl, C. M., O’Dell, C., Mandrake, L., Viatte, C., Kiel, M., Griffith, D. W. T., Deutscher, N. M., Velazco, V. A., Notholt, J., Warneke, T., Petri, C., De Maziere, M., Sha, M. K., Sussmann, R., Rettinger, M., Pollard, D., Robinson, J., Morino, I., Uchino, O., Hase, F., Blumenstock, T., Feist, D. G., Arnold, S. G., Strong, K., Mendonca, J., Kivi, R., Heikkinen, P., Iraci, L., Podolske, J., Hillyard, P. W., Kawakami, S., Dubey, M. K., Parker, H. A., Sepulveda, E., García, O. E., Te, Y., Jeseck, P., Gunson, M. R., Crisp, D., and Eldering, A.: Comparisons of the Orbiting Carbon Observatory-2 (OCO-2) $X_{\mathrm{CO}_{2}}$ measurements with TCCON, Atmos. Meas. Tech., 10, 2209-2238, https://doi.org/10.5194/amt10-2209-2017, 2017.

Yokota, T., Yoshida, Y., Eguchi, N., Ota, Y., Tanaka, T., Watanabe, H., and Maksyutov, S.: Global concentrations of $\mathrm{CO}_{2}$ and $\mathrm{CH}_{4}$ retrieved from GOSAT: first preliminary results, Sola, 5, 160-163, https://doi.org/10.2151/sola.2009-041, 2009. 